\title{
OUTPATIENT MANAGEMENT OF LOW VELOCITY GUNSHOT WOUND EXPERIENCE IN UNITED NATIONS LEVEL-II HOSPITAL
}

\author{
Rahman $\mathrm{M}^{1}$, Sikder $\mathrm{AI}^{2}$, Haque $\mathrm{M}^{3}$, Asaduzzaman $\mathrm{AKM}^{4}$
}

\begin{abstract}
Introduction: Gunshot wounds are commonly encountered in war as well as in civilian situation. Experience of treating low velocity gunshot wounds (GSW) as outpatients in a war situation is depicted in this study.

Aim: The aim of this study was to evaluate the experience of treating low velocity gunshot wounds by simple wound irrigation and marginal excision in war situation.

Method: This was a retrospective observational study carried out in a Level-II Hospital of United Nations in Ivory Coast over a period of 7 months. All patients of low velocity GSW were treated with simple wound irrigation with normal saline and povidone iodine solution with excision of wound margin of doubtful viability under local anesthesia, rather than wound debridement.

Result: All wounds healed with $6 \%$ superficial wound infection that was controlled with oral antibiotics.

Conclusion: Outpatient management of low velocity GSW with wound irrigation and marginal excision is an effective method of treatment that can save time, money and hospital-stay.
\end{abstract}

Keyword: Gunshot wound, irrigation, marginal excision

\section{Introduction}

Long continued political unrest lead United Nations (UN) to deploy troops in Cote d'Ivoire. At the climax of unrest a formal war began. During war time the facilities of government hospital and doctors were inadequate. UN established a level-II hospital in a remote district where modern hospital facilities were lacking and at present this is the only hope for the regional war victims. As a result, many civil war casualties rushed to UN level-II hospital at Daloa, which by dint of its mission and capability is unable to provide indoor treatment to those civilian patients except special cases. Considering the situation and the volume of non entitled patients this hospital adopted a conservative outpatient approach for some selected war victims.

This retrospective study was designed to evaluate the response of the result of simplified treatment offered to the patients with low velocity gunshot wounds in a war situation.

\section{Materials and Methods}

This was a retrospective observational study. It was carried out in Orthopedic and Trauma department of Bangladesh Medical (BANMED) Level-II hospital at Daloa, Cote D'Ivoire. The study period was February to August 2011. Data were collected from hospital emergency register, emergency operation theatre register and central operation theater register. All patients of low velocity Gunshot Wounds (GSW) were selected according to the laid down criteria mentioned below.

Inclusion criteria

- Wound involving soft tissue only

- Not associated with vessel, nerve or bony injury that requires surgical intervention

- Entry or exit wound $\leqslant 2 \mathrm{~cm}$ in diameter

- No evidence of tissue necrosis

- Not grossly contaminated

- Joints are not involved

Exclusion criteria

- Wound $>2 \mathrm{~cm}$ in diameter

- Evidence of infection

- Reported with evidence of tissue necrosis

- Wounds involving fractures, joint and major vessels and nerves

- A palpable cavity beneath the surface

- Serous or serosanguinous discharge with pressure on the wound

- Puncture wounds whose local exploration demonstrates depth of penetration

All relevant data like patient's age, sex, time of injury, time interval between injury and hospital reporting, treatment in emergency department, investigations, number of reviews, complications, follow up and patient outcome were taken on Microsoft Excel spreadsheet and analyzed. All the continuous data were expressed as mean and categorical data in percentage (\%) and frequency (f).

Treatment regimen: All gunshot victims, reporting to emergency department, passed through a standard set protocol of treatment that consisted of a quick concise history, emergency resuscitation as per standard Advanced Trauma Life Support (ATLS) protocol (A, B, $\mathrm{C}, \mathrm{D}$, and $\mathrm{E}$ ), necessary investigations (blood grouping

1. Lt Col Moklesur Rahman MBBS, MS (Ortho), Fellow Hand (Thai), Level-II Hospital, United Nations Operations in Ivory Coast (UNOCI), Daloa, Ivory Coast; 2. Lt Col Aminul Islam Sikder MBBS, FCPS, Level-II Hospital, UNOCI; 3. Lt Col Mozibul Haque MBBS, FCPS Level-II Hospital, UNOCI; 4. Lt Col AKM Asaduzzaman MBBS, FCPS, Level-II Hospital, UNOCI. 
and cross matching, HIV Ab, Serum creatinine, X-ray), a parenteral dose of diclofenac sodium, Tetanus prophylaxis (if not already immunized or gave doubtful history) and a bolus dose of intravenous ceftriaxone. All patients fulfilling the inclusion criteria for outpatient management were taken to emergency operation theatre. The wounds were thoroughly cleaned of gross dust and foreign particles with surgical scrub brush and solution. The wound tracks were then forcefully irrigated with profuse normal saline and povidone iodine solution. Only easily accessible pellets were removed or attempted to be removed. Wound (entry or exit) margins were minimally excised or trimmed in case of doubtful viability. Wounds were lightly packed with povidone iodine soaked gauze and pressure dressing applied. Dressing changed after 48 hours, 72 hours and thereafter daily if there was evidence of infection and continued till wound became fit for secondary closure. Wounds were closed either by delayed primarily or secondarily.

\section{Result}

In total 76 patients of GSW reported to the hospital during the study period. Among them 12 were untraceable during follow up, 14 did not fit into inclusion criteria because of presence of associated injuries (vessel, nerves and bone) that required intervention. So, 50 patients with 58 GSW were studied (Table-I). Four patients had multiple injuries. Out of fifty patients male predominates $(82 \%)$. Age range was $4-71$ years with mean age 30 years.

Table-I: Distribution of cases as per age and sex $(n=50)$

\begin{tabular}{|l|c|c|c|}
\hline $\begin{array}{l}\text { Age Group } \\
\text { (in years) }\end{array}$ & $\begin{array}{c}\text { Male } \\
\mathbf{f}(\%)\end{array}$ & $\begin{array}{c}\text { Female } \\
\mathbf{f}(\%)\end{array}$ & $\begin{array}{c}\text { Total } \\
\mathbf{f}(\mathbf{\%})\end{array}$ \\
\hline 20 & $08(19.5)$ & $3(33.3)$ & $11(22)$ \\
\hline $21-40$ & $25(60.9)$ & $3(33.3)$ & $28(56)$ \\
\hline $41-60$ & $04(09.8)$ & $3(33.3)$ & $07(14)$ \\
\hline$>60$ & $04(09.8)$ & $0(00)$ & $04(08)$ \\
\hline Total & $41(100)$ & $9(100)$ & $50(100)$ \\
\hline
\end{tabular}

Majority of patients reported within 6-12 hours of injury with highest percentage $(4 \%)$ of infection in late $(>12$ hour) presentation group (Table-II). Total $92 \%$ of study population had only soft tissue injury; remaining $8 \%$ had associated bony injuries that were treated conservatively. Patients with associated fractures that required primary fixation and hospital admission were excluded from the study. Distribution of soft tissue injury (Fig 1) revealed that lower limb was involved in highest percentage $(72 \%)$ of cases. The maximum number of complications $(8 \%)$ encountered was superficial wound infection $(6 \%)$ that cured with repeated dressing (Table-III). All patients received total three doses (1 gm daily) of intravenous ceftriaxon. Those who developed infection received an additional dose of oral ciprofloxacin (500 mg 12 hourly) for 5 days. Total 40(69\%) wounds were closed delayed primarily within 4-6 days and the remaining 18(31\%) were closed secondarily. All fractures were united without any complication.

Table-II: Time interval between injury and treatment with infection rate.

\begin{tabular}{|l|c|c|}
\hline $\begin{array}{l}\text { Time between injury } \& \\
\text { wound care (hours) }\end{array}$ & $\begin{array}{c}\text { Cases } \\
\mathbf{f}(\%)\end{array}$ & $\begin{array}{c}\text { Infection } \\
\mathbf{f}(\%)\end{array}$ \\
\hline 6 & $14(28)$ & $0(0)$ \\
\hline $6-12$ & $24(48)$ & $1(2)$ \\
\hline$>12$ & $12(24)$ & $2(4)$ \\
\hline Total & $50(100)$ & $3(6)$ \\
\hline
\end{tabular}



Fig-1: Pie diagram of soft tissue injury.

\section{Discussion}

According to muzzle velocity of weapon, GSW are classified into low velocity and high velocity wounds. Low and high velocity wounds are caused by guns with a muzzle velocity of $<2000 \mathrm{feet} / \mathrm{sec}$ and $>2000 \mathrm{feet} / \mathrm{sec}$ respectively ${ }^{1}$. The amount of energy transferred in low velocity wound is $100-50 \mathrm{~J}$ and can be measured by the formula $\mathrm{KE}=1 / 2 \mathrm{M}\left(\mathrm{V}^{2}{ }^{2}-\mathrm{V}^{2}\right)$ where $\mathrm{KE}=$ available energy, $\mathrm{M}=$ mass, $\mathrm{V} 1$ and $\mathrm{V} 2$ are the velocities at entry and exit ${ }^{2}$. It damages tissue by transferring all or part of its available energy. Low velocity GSW has got two effects on tissue; sonic pressure wave and permanent cavitations. Sonic pressure wave is of short duration, precedes bullet and does not cause much tissue destruction. Permanent cavitations is caused mainly by crushing and laceration of tissues along the missile track $^{3,4}$. In low energy transfer wound tissue destruction is confined to wound track producing permanent cavity and is proportional to the size of the projectile. The severity of the injury depends on two factors ${ }^{3,4}$ e.g. bullet factors (velocity, mass, shape and design of the projectile, caliber of the projectile, entrance profile i.e. in which degree the bullet enters the body) and tissue factors ( distance traveled within the body, biological characteristics of impacted tissue, mechanism of tissue disruption). Depending upon the elasticity, density and cohesiveness, several tissues behave differently and tissue destruction occurs accordingly. So with the same 
amount of energy transfer liver is more severely traumatized than skeletal muscle ${ }^{4}$. The devitalized tissue along the wound track especially skeletal muscle produces perfect culture media for bacterial growth. Blood vessels and nerves respond unpredictably ranging from bruising to complete disruption ${ }^{2}$.

The success of war wound surgery depends on strict adherence to four basic principle i.e. meticulous wound cleaning/debridement, immobilization, delayed wound coverage and antibiotics. Meticulous recording and preservation of all findings, photographs and forensic evidence should be done in all civilian cases $^{5,6}$. In a study of 90 low velocity GSW Byrne $\mathrm{A}^{\text {et }} \mathrm{al}^{7}$ reported $70.5 \%$ soft tissue injury only. In another study by Ritchie et $\mathrm{al}^{8}$ observed that only soft tissue injury was $58 \%$. In present study $92 \%$ patient had only soft tissue injury. The difference of result may be due to the exclusion criteria of the study. All possible cases that had systemic injury and required surgical intervention were discarded. Here only 4 cases that had associated fracture but could be managed conservatively were included.

In a series of GSW management Ordog et $\mathrm{al}^{9}$ reported that $60 \%$ of the patients required treatment as outpatients with $1.8 \%$ infection rate and overall direct complication rate was $20 \%$. Byrne et $\mathrm{al}^{7}$ treated $74 \%$ patient as outpatients and the minor complication rate was $5.3 \%$. In reported series the overall complication rate was $6 \%$ and superficial wound infection was the only complication. Although many author disagree ${ }^{3,9,10}$ with routine antibiotic use in low velocity GSW, antibiotics was prescribed in all cases of this study. In spite of routine antibiotic use here infection rate was high in comparison to others. This may be due to poor personal cleanliness, unhygienic living condition, irregularity in dressing change and antibiotic intake, making the dressing dirty, poor nutritional status and poor compliance. The risk factors for wound infection are delay in wound care, inadequate wound management, failure to comply with instructions of wound care? .
Table-III: Outcome of OPD treatment of low velocity GSW by study

\begin{tabular}{|l|l|l|l|}
\hline Legend & $\begin{array}{l}\text { Byrne A } \\
\text { et al }^{\mathbf{7}}\end{array}$ & $\begin{array}{l}\text { Ordog } \\
\text { et al }^{\mathbf{9}}\end{array}$ & $\begin{array}{l}\text { Present } \\
\text { study }^{-}\end{array}$ \\
\hline $\begin{array}{l}\text { Skin \& soft tissue } \\
\text { injury only }\end{array}$ & $70.5 \%$ & 00 & $92 \%$ \\
\hline Outpatient treatment & $74 \%$ & $60 \%$ & $100 \%$ \\
\hline Minor complication rate & $5.3 \%$ & $1.8 \%$ & $6 \%$ \\
\hline
\end{tabular}

\section{Conclusion}

Gunshot wound usually involves a composite structure of muscle, vessel and nerves. Simple wound irrigation and marginal excision under local anesthesia is an effective method of treatment for low velocity GSW. Although there is some dilemma of differentiation between low and high velocity wound it can safely be overcome by meticulous wound examination and strict adherence to inclusion and exclusion criteria.

\section{References}

1. Bartlet CS, Helfet DL, Hausman MR, Strauss E. Ballistics and gunshot wounds: effects on musculoskeletal tissues. J Am Acad Orthop Surg 2000; 8(1): S21-36.

2. Ryan JM. Warfare injuries. In: Russell RCG, Williams NS, Bulstrode CJK, editors. Baily \& Love's Short Practice of Surgery. 24th ed. London: Arnold, a member of the Hodder Headline Group; 2004. p. 292-301.

3. Lichte P, Oberbeck R, Binnebosel M, Wildenaeur HC, Kobbe PP. A civilian perspective of ballistic trauma and gunshot injuries. Scand $\mathrm{J}$ Trauma Resusc Med 2010; 18:35.1-13.

4. Brown CC, McQueen MM, Tornetta III P. Gunshot Injuries. In: Tornetta III P, Einhorn TA, editors. Orthopedic surgery essentials: Trauma. London: Lippincott Williams and Wilkins; 2006. p. 27-31.

5. Bowyer GW, Rossiter ND. Management of gunshot wounds of the limbs. J Bone joint Surg (Br) 1997; 79: B1031-1036.

6. Swan KG, Swan RC. Principles of ballistics applicable to the treatment of gunshot wounds. Surgical Clinics of North America 1991; 71: 221-39.

7. Byrne A, Curran P. Necessity breeds invention: a study of outpatient management of low velocity gunshot wounds. Emerg Med J 2006; 23(5): 376-378.

8. Ritchie AJ, Harvey CF. Experience in low velocity gunshot injuries: a more conservative approach in selected cases. J R Coll Surg Edinb 1990; 35:302-304.

9. Ordog GJ, Wesserberger JS, Balasubramanium S. Civilian gunshot wounds: outpatient management. J Trauma1991; 36:106-111.

10. Simpson BM, Wilson RH, Grant RE. Antibiotic therapy in gunshot wound injuries. Clin Orthop Relat Res.2003:82-85. 